Vol.5 No.2

\title{
PKM MITRA USAHA RUMAH MAKAN DI DESA PINELENG I KECAMATAN PINELENG KABUPATEN MINAHASA PROVINSI SULAWESI UTARA
}

Irvan Trang

Universitas Sam Ratulangi

A R T I C LE IN F O

\begin{abstract}
Keywords : Entrepreneurs, Business Partners of an Eating House, The Pineleng I Village
\end{abstract}

Kata Kunci : Wirausaha, Mitra Usaha Rumah Makan, Desa Pineleng I

Corresponding author : Irvan Trang trang_irvan@yahoo.com

\begin{abstract}
Business development is one engine of Indonesia for economic development in the country. This is in accordance with the main purpose of entrepreneurship is economic growth. In the Pineleng I village / type is a great variety of small and medium businesses UMKM and they are new or old operate. Pratiwi and muslims and restaurant business was one business unit located in the business / pineleng I owned by Mr. abdul sagiyo and Mr. rivan efendi.

The goal of the program partnership the community this is to provide counseling, training and assist restaurants partners business that existed in the Pineleng village. The result is the ability to create new ideas pertaining to food product, restaurants service. Next, the ability make the books and budget simple (financial reporting in a transparent, the capacity to think fast, act creative and innovative, decision-making and produce products and restaurants services. The ability to create an idea, innovation, restaurants service and intelligence, ingenuity and carefulness put in place a strategy for promotion and marketing
\end{abstract}

Abstrak : Pengembangan usaha merupakan salah satu motor penggerak bagi pembangunan ekonomi di negara Indonesia. Hal ini sesuai dengan tujuan utama dari kewirausahaan adalah Pertumbuhan Ekonomi Nasional. Di Desa Pineleng I terdapat berbagai macam bentuk/jenis UMKM dan UKM yang masih baru ataupun sudah lama beroperasi. Usaha Rumah Makan Pratiwi dan Rumah Makan muslim adalah salah satu unit usaha/bisnis yang bertempat di Desa Pineleng I yang dimiliki oleh Bapak Abdul Sagiyo dan Bapak Rivan Efendi Tujuan dari program kemitraan masyarakat ini adalah untuk memberikan penyuluhan, pelatihan dan pendampingan bagi mitra usaha rumah makan yang ada di Desa Pineleng. Hasilnya adalah Kemampuan untuk menciptakan ide-ide baru berkaitan dengan produk makanan, jasa pelayanan rumah makan. Selanjutnya, kemampuan membuat pembukuan dan anggaran sederhana (pelaporan keuangan secara transparan, kemampuan berpikir cepat, bertindak kreatif dan inovatif, pengambilan keputusan serta menghasilkan produk dan jasa pelayanan rumah makan. Kemampuan untuk menciptakan suatu ide, inovasi, jasa pelayanan rumah makan serta kecerdasan, kecerdikan dan kejelian membuat suatu strategi promosi dan pemasaran. 


\section{PENDAHULUAN}

\section{Latar Belakang}

Pada Era Asean Economic Community (AEC) saat ini sangat dibutuhkan pelaku-pelaku bisnis yang memiliki kreativitas dan inovasi serta inisiasi usaha-usaha baru yang mampu mengubah potensi tersebut menjadi produk dan jasa yang dibutuhkan oleh pasar sehingga mendapat nilai tambah dari potensi yang dimiliknya. Pelaku-pelaku usaha juga saat ini harus memiliki soft skill: 1. Kemampuan berkomunikasi, 2. Bisa menjadi warga negara yang baik, 3. Bertanggung jawab. Sebagai pelaku usaha memiliki peran penting untuk dikembangkan dan diberdayakan. Pengembangan usaha merupakan salah satu motor penggerak bagi pembangunan ekonomi di negara Indonesia. Hal ini sesuai dengan tujuan utama dari kewirausahaan adalah "National Economic Growth" Pertumbuhan Ekonomi Nasional. Menurut Ciputra (Nugroho, 2013), wirausahawan merupakan mereka yang mampu mengubah sampah menjadi emas, Gabage In Gold Out (GIGO), serta berjuang berkontribusi pada kebaikan dan kesejahteraan masyarakat. Sejalan dengan itu, Hikmat (2006;3) mengemukakan bahwa konsep pemberdayaan masyarakat dalam pembangunan dihubungkan dengan mandiri, partisipasi, jaringan kerja dan keadilan. Konsep pemberdayaan berusaha menyempurnakan konsep pembangunan yang hanya berpihak pada elit, kekuasaan dan ikut dalam kemapanan. Menurut Indarti (2008), untuk mencapai tujuan pemberdayaan kita telah mengenal adanya dua pendekatan. Pertama, dengan merubah sikap sumber daya manusia yang kemudian diharapkan akan berpengaruh terhadap perubahan perilaku. Kedua, dengan merubah perilaku sumber daya manusia terlebih dahulu kemudian diharapkan berpengaruh terhadap perubahan sikap.

Di Desa Pineleng I terdapat berbagai macam bentuk/jenis UMKM dan UKM yang masih baru ataupun sudah lama beroperasi, hal ini tentunya berdasarkan tuntutan bahwa mereka semua harus bergerak untuk memenuhi kebutuhan mereka masing-masing, tidak terkecuali dengan usaha-usaha seperti rumah makan. Rumah Makan Pratiwi dan Rumah Makan Muslim adalah salah satu unit usaha/bisnis yang bertempat di Desa Pineleng I Kecamatan Pineleng Kabupaten Minahasa Provinsi Sulawesi Utara yang dimiliki oleh Bapak Abdul Sagiyo dan Bapak Rivan Efendi. Usaha mereka ini bergerak dalam bidang kuliner (makanan). Usaha mereka sudah berjalan kurang lebih 2 (Dua) Tahun, dimana sesuai dengan Motto usaha ini adalah "pelayanan adalah prioritas". Berdasarkan data yang diperoleh bahwa orang yang berkunjung dan makan/minum di rumah makan pratiwi dan rumah makan muslim \pm 50 pengunjung per hari. Rumah makan pratiwi dan rumah makan muslim sampai saat ini memiliki 2 orang Pekerja baik sebagai juru masak sekaligus pelayan makanan. Selanjutnya, kedua rumah makan ini juga mempunyai pendapatan (omset) \pm Rp 500.000 Per hari, hitungan ini berdasarkan formulasi setiap pengunjung yang datang dan makan serta minum di rumah makan tersebut, sungguh merupakan pendapatan (omset) yang lumayan bagus ketika semua orang mau berpikir seperti itu. Artinya, ketika banyak orang berpendapat bahwa itu merupakan masalah tapi hal itu peluang menurut kita. Seiring waktu usaha ini berjalan terdapat berbagai macam bentuk permasalahan antara lain adalah faktor persaingan (competitor), promosi dan pemasaran, keluasan tempat usaha dan lain-lain. Hal inilah yang mendorong kami Tim pengabdian masyarakat dalam Program Kemitraan Masyarakat (PKM) Unsrat untuk melakukan Analisis dan Kajian serta memberikan solusi bagi persoalan-persoalan yang dihadapi Mitra Usaha/Masyarakat. Untuk itu Judul Program Kemitraan Masyarakat (PKM) yang diambil adalah "PKM Mitra Usaha Rumah Makan Di Desa Pineleng I Kecamatan Pineleng Kabupaten Minahasa Provinsi Sulawesi Utara".

\section{Manajemen Sumber Daya Manusia}

\section{TINJUAN PUSTAKA}

Menurut Dessler (2011:5) manajemen sumber daya manusia sebagai kebijakan dan praktik menentukan aspek manusia atau sumber daya manusia dalam posisi manajemen, termasuk merekrut, menyaring, melatih, memberi penghargaan dan penilaian. Perusahaan atau organisasi tentunya menginginkan agar setiap saat memiliki sumber daya manusia yang berkualitas dalam arti memenuhi persyaratan kompetensi untuk didayagunakan dalam usaha merealisasi visi dan mencapai tujuan-tujuan jangka menengah dan jangka pendek.

Malayu S.P Hasibuan, (2007:6) berpendapat bahwa Manajemen Sumber Daya Manusia adalah ilmu dan seni yang mengatur hubungan dan peranan tenaga kerja agar efektif dan efisien untuk membantu terwujudnya tujuan perusahaan dan masyarakat. 


\section{Pengembangan Karir}

Menurut Mangkunegara (2001:77) Pengembangan karir adalah aktivitas kepegawaian yang membantu pegawai-pegawai merencanakan karir masa depan mereka di perusahaan agar perusahaan dan pegawai yang bersangkutan dapat mengembangkan diri secara maksimum. Menurut Rivai (2008: 290) pengembangan karir adalah proses peningkatan kemampuan kerja individu yang dicapai dalam rangka mencapai karir yang diinginkan.

Pengembangan karir tercermin dalam gagasan bahwa orang selalu bergerak lebih maju dan meningkat dalam pekerjaan yang dipilihnya. Bergerak maju berarti kenaikan gaji yang lebih besar dengan tanggung jawab yang lebih besar pula. Menurut Handoko (2001 :121) Suatu karir adalah semua pekerjaan atau jabatan yang dipunyai selama kehidupan kerja seseorang. Dalam perencanaan karir seseorang pegawai memang tidak menjamin keberhasilan karir karena walaupun sudah dirancang sedemikian rupa akan tetapi sikap atasan, faktor pengalaman, pendidikan dan juga nasib seseorang sangat mendukung dalam keberhasilan karir seseorang.

\section{Wirausaha}

Istilah wirausaha memiliki banyak kata yang seringkali diartikan sama yaitu wiraswasta, pebisnis, entrepreneur, technoprenur, social technopreneur, pengusaha, pedagang, saudagar dan wirausaha yang mengacu pada kata dari bahasa Inggris yaitu entrepreneur yang bermakna berusaha atau mengusahakan secara mandiri, terutama mengacu pada seseorang yang berusaha/membuka usaha baru. Secara teori bahwa kewirausahaan adalah proses dimana seseorang bisa menciptakan sesuatu yang baru, berbeda dan bisa menjadi nilai tambah serta berguna bagi orang dan masyarakat dengan menerapkan strategi Analisis, tiru dan modifikasi (McClelland dalam Trang, 2016).

Sejalan dengan itu, Hikmat (2006;3) mengemukakan bahwa konsep pemberdayaan masyarakat dalam pembangunan dihubungkan dengan mandiri, partisipasi, jaringan kerja dan keadilan. Konsep pemberdayaan berusaha menyempurnakan konsep pembangunan yang hanya berpihak pada elit, kekuasaan dan ikut dalam kemapanan.

Kinerja wirausaha adalah hasil kerja yang dapat dicapai seseorang atau sekelompok orang dalam suatu organisasi, sesuai dengan wewenang dan tanggung jawab masing-masing, dalam rangka mencapai tujuan organisasi bersangkutan secara legal, tidak melanggar hukum dan sesuai dengan moral maupun etika (Suradji 2003:2)

Istilah kinerja berasal dari kata job performance atau actual performance (prestasi kerja atau prestasi sesungguhnya yang dicapai seseorang). Pengertian kinerja adalah hasil kerja secara kualitas dan kuntitas yang dicapai seorang karyawan dalam melaksanakan tugasnya sesuai dengan tanggung jawab yang diberikan kepadanya (Mangkunegara (2001:67).

\section{METODE PENDEKATAN}

Metode pendekatan dan pelaksanaan oleh tim Program Kemitraan Masyarakat (PKM) adalah untuk mendukung realisasi program ini dengan mengadakan penyuluhan, pelatihan dan pendampingan. Sedangkan asumsi dasar program ini adalah bahwa para mitra usaha yang menjadi target (target khalayak) sudah pernah ataupun belum pernah mendapatkan pelatihan ini sehingga mereka sangat membutuhkan keterampilan dan pengetahuan ini.

Lingkup batasan penerapan ipteks pada program ini adalah: (1) berbentuk pelatihan kepada mitra; (2) bertujuan memberikan pengetahuan, keterampilan, serta kecakapan manajemen, kewirausahaan, kreativitas, inovasi/ide usaha, pemasaran, SDM, penggunaan teknologi informasi, pengelolaan keuangan. Penerapan program ini ditempuh dengan cara penyuluhan, pelatihan dengan metode praktis, studi kasus, latihan-latihan serta pendampingan.

Kriteria dan indikator yang digunakan untuk menyatakan keberhasilan dari kegiatan yang dilakukan ini adalah:

a. Pemahaman teori dan konsep manajemen bisnis, kewirausahaan, kreativitas, inovasi dan kepemimpinan

b. Kemampuan untuk menciptakan ide-ide baru berkaitan dengan produk makanan, jasa pelayanan dan usaha rumah makan

c. Kemampuan membuat pembukuan dan anggaran sederhana (pelaporan keuangan secara transparan)

d. Kemampuan berpikir cepat, bertindak kreatif dan inovatif, pengambilan keputusan serta menghasilkan produk dan jasa pelayanan rumah makan

e. Kemampuan untuk menciptakan suatu ide, inovasi, jasa pelayanan rumah makan 
f. Kecerdasan, kecerdikan dan kejelian membuat suatu strategi promosi dan pemasaran

g. Qiuck Respons terhadap pasar

h. Kemampuan menggunakan Teknologi Informasi (IT)

Dalam metode pelaksanaan kegiatan terkait dengan permasalahan mitra usaha (rumah makan pratiwi dan rumah makan muslim), maka terdapat langkah-langkah dalam 3 aspek kegiatan yang ada, yakni :

1. Bidang Produksi

Dengan menggunakan sistem metode first in first out (FIFO) pada penerimaan (order) pesanan makanan dimana konsumen pertama yang memesan maka konsumen pertama itulah yang lebih dahulu diproses, mulai dari proses pemilihan menu makanan dan minuman, pembuatan makanan oleh juru masak (chef), sampai pada proses penyajian makanan.

2. Bidang Manajemen

Dengan adanya proses penyuluhan, pelatihan dan pendampingan dari Tim Program Kemitraan Masyarakat (PKM) maka kedua mitra usaha ini bisa mengaplikasikan fungsi-fungsi manajemen yang ada, seperti Perencanaan mereka dalam hal menyediakan bahan baku untuk makanan, proses pembuatan makanan, perencanaan mengenai promosi atau memperkenalkan menu (spect) makanan mereka, perencanaan dalam memasarkan pelayanan antar makanan/minuman dengan menggunakan Go-Food (delivery time). Kemudian, kedua mitra usaha ini harus membuat situs (websitei) sendiri sehingga bisa mengakomodir bentuk promosi online mereka disosial media. Selanjutnya, pengorganisasian yang harus dilakukan dalam mengkoordinasi para pekerja, baik pekerja dibagian pembelian bahan baku, juru masak, pelayan dan penyaji makanan dan pengiriman makanan. Pengorganisasian ini dianggap perlu agar supaya tercipta budaya kerja yang bertanggung jawab dan bagaimana menempatkan orang yang tepat pada posisi yang tepat (the right man on the right place). Selanjutnya, sistem pengendalian (controlling) dalam manajemen usaha perlu dilakukan, dimana para pekerja ini harus terus dikontrol karena hal ini sangat berkaitan dengan kinerja para pekerja, indikator kinerja tidak lepas dari kualitas kerja, kuantitas kerja dan ketepatan waktu yang dihasilkan. Pihak mitra usaha rumah makan juga harus memperhatikan Kepemimpinan (leading) yang ada di manajemen usaha tersebut, dengan fokus pada gaya kepemimpinan seorang pemilik usaha rumah makan yang transformasional, partisipatif dan kharismatik. Secara keseluruhan bahwa kedua mitra usaha rumah makan ini harus melakukan kegiatan manajemen dalam semua aspek yang berhubungan dengan Input - Proses - Output sampai Feedback (Evaluasi) sehingga tercipta Kepuasan Pelanggan (loyal)

3. Bidang Pemasaran

Selanjutnya, dengan adanya penyuluhan, pelatihan dan pendampingan dari Tim Program Kemitraan Masyarakat (PKM) maka kedua mitra usaha ini bisa menggunakan teknologi informasi, jaringan internet (networking) dalam mempromosikan (memperkenalkan) serta memasarkan spect-spect menu makanan mereka, seperti : Nasi ayam lalapan, nasi rawon, gado-gaado, soto ayam, nasi goreng, coto maksar, dan lain-lain. Penggunaan teknologi informasi ini juga bisa mempercepat akses promosi kedua mitra usaha pada masyarakat yang tidak hanya berdomisili di Desa Pineleng I saja tetapi bisa merambah ke luar Desa termasuk Perkotaan ketika mereka lewat dan singgah makan di kedua rumah makan tersebut.

\section{HASIL DAN PEMBAHASAN}

Lembaran Negara Nomor 64 Tahun 1919, minahasa di jadikan daerah otonom. Pada saat itu minahasa terbagi dalam 16 distrik : distrik tonsea, manado, bantik, maumbi, tondano, touliang, tomohon, sarongsong, tombariri, sonder, kawangkoan, rumoong, tombasian, pineleng, tonsawang, dan tompaso. Tahun 1925, 16 distrik tersebut dirubah menjadi 6 distrik yaitu distrik manado, tonsea, tomohon, kawangkoan, ratahan, dan amurang. Sejalan dengan perkembangan otonomi maka tahun 1919, kota Manado yang berada di tanah Minahasa, diberikan pula otonom menjadi Wilayah Kota Manado.

Dalam rangka untuk meningkatkan daya guna dan hasil guna dalam rentang kendali penyelenggaraan tugas pemerintahan, pelaksanaan pembangunan serta pembinaan dan pelayanan masyarakat usulan pembentukan kabupaten Minahasa Induk diproses bersama-sama dengan 25 calon Kabupaten/Kota diseluruh Indonesia, dan setelah melalui proses persetujuan DPR-RI, maka Kabupaten Minahasa Induk ditetapkan menjadi Kabupaten dan Kota Otonom di Indonesia melalui UU Nomor 10 tahun 2003 tertanggal 25 Pebruari 2003. Pada tanggal 21 
Nopember 2003 dengan UU Nomor 33 Tahun 2003, Kabupaten Minahasa Induk ditetapkan menjadi daerah otonom yang baru. Kabupaten Minahasa Induk pada tanggal 23 Mei 2007 juga telah memekarkan Kabupaten Minahasa Tenggara. Dengan adanya Pemekaran tersebut maka wilayah Minahasa menjadi 4 (empat) Kabupaten (Kabupaten Minahasa Induk, Minahasa Selatan, Minahasa Utara, Minahasa Tenggara) dan 3 (tiga) Kota (Kota Manado, Bitung dan Tomohon).

Secara khusus Profil Desa Pineleng adalah sebuah kecamatan di kabupaten Minahasa, Sulawesi Utara, Indonesia dimana sebelah utara berbatasan dengan Kota Manado dan Laut Sulawesi, Timur dengan kecamatan Tombulu dan Kota Tomohon, Selatan kota Tomohon dan Barat dengan Kecamatan Tombariri.

Kabupaten Minahasa Induk adalah salah satu kabupaten di provinsi Sulawesi Utara, Indonesia. Ibu kota kabupaten ini terletak di Tondano. Kabupaten ini memiliki luas wilayah 1.025,85 km². Pada 25 Februari 2003 Kabupaten Minahasa dimekarkan menjadi Kabupaten Minahasa Induk, Kabupaten Minahasa Selatan dan Kota Tomohon berdasarkan UU No.10/2003. Pada tanggal 18 Desember 2003 Kabupaten Minahasa dimekarkan lagi menjadi Kabupaten Minahasa dan Kabupaten Minahasa Utara berdasarkan UU No. 33/2003.

Ibu kota Kabupaten Minahasa Induk, Tondano, dengan luas $4.626 \mathrm{~km} \hat{A}^{2}$. Jumlah penduduk pada $2016 \pm$ 490.771 jiwa. Pembagian administratif meliputi 25 kecamatan. Saat ini dipimpin Bupati Drs. Jantje Satjouw, M.Si dan Wakil Bupati Ivan Sarundajang. Kabupaten Minahasa memiliki satu Universitas Negeri, yaitu Universitas Negeri Manado (UNIMA), Kampus Biru Tounsaru Tondano Selatan dan satu Sekolah Tinggi Swasta, yaitu Sekolah Tinggi Filsafat Seminari Pineleng. Dalam hal pendidikan, Kota Tondano terdapat 8 Sekolah Lanjutan Tingkat Atas (SLTA), di beberapa kota dan kecamatan terdapat rata-rata dua hingga tiga SLTA saja, kemudian terdapat juga SLA (Sekolah Lanjutan Advent) yang sangat terkenal dengan Hari Sabat di dalam kitab suci yang satu-satunya sekolah Lanjutan Advent. Selanjutnya berbicara seni dan olahraga, terdapat seniman terkenal seperti JE. Tatengkeng, Mr. Dajoh, Yessy Wenas, Maya Rumantir, Chintya Maramis dan Angel Karamoy. Dalam bidang seni diadakannya kontes putra putri Se-Minahasa Waraney dan Wulan Minahasa. Klub Sepak Bola daerah ini bernama Persmin. Para pemain sepak bola yang terkenal asal Minahasa seperti Ronny Pangemanan dan Yopie Lumoindong (Tondano) di PSM Makassar dan sebagainya.

Pineleng adalah sebuah kecamatan di Kabupaten Minahasa, Sulawesi utara, Indonesia sebelah utara berbatasan dengan Kota manado dan laut sulawesi. Bagian Timur berbatasan dengan kecamatan Tombulu dan Kota Tomohon dan Bagian barat berbatasan dengan kecamatan tombariri. Desa-desa yang berada di Kecamatan Pineleng, yakni :

1. Pineleng Satu

2. Pineleng Dua

3. Pineleng Satu Timur

4. Sendangan

5. Kali

6. Warembungan

7. Winangun Atas

8. Sea

9. Sea Saturday Sea Dua

10. Kalasey satu

11. Kalasey Dua

12. Tateli

13. Tateli Weru

14. Koha

15. Agotey

Di Pineleng ini terdapat sekolah tinggi filsafat seminari (katolik) keuskupan Manado. Terdapat Masjid Imam Bonjol Pineleng berlokasi di jalan raya manado-Tomohon, kemudian Masjid Al-Mustaqim Pineleng 2. Terdapat Monumen Makam Pahlawan Nasional Imam Bonjol yang terletak di Desa lotta Kali Pineleng serta lokasi pemandian air terjun tapahan telu. Selanjutnya bersuku Minahasa dengan mayoritas agama kristen katolik, protestan dan minoritas beragama Islam.

Pineleng dengan luas wilayah $\pm 84,08 \mathrm{Km} 2$, dengan jumlah penduduk \pm 34.822 Jiwa serta kepadatan 415 jiwa/Km2. Di pineleng ini terdapat Sekolah Tinggi Filsafat Seminari (Katolik) keuskupan Manado, Monumen/Makam Pahlawan Nasional Imam Bonjol terletak di lotta-kali Pineleng, selanjutnya beraneka ragam 
budaya dan suku dimana terdapat suku minang dan tondano dengan agama Islam, kristen katolik dan protestan.

Kehadiran Desa Pineleng I sebagai wilayah dari Kabupaten Minahasa Induk patut menajdi perhatian bagi pemerintah dalam rangka mengembangkan taraf hidup masyarakat yang mempunyai perekonomian yang matang, apalagi dalam era Asian Economic Cimunity (AEC) yang ada saat ini serta ditengah krisis yang melanda sebagian besar wilayah global tentunya berdampak signifikan bagi masyrakat yang berpenghasilan menengah ke bawah maka dari itu Tim Program Kemitraan Masyarakat (PKM) memiliki inisiatif untuk melakukan kegiatan ini dengan metode penyuluhan, pelatihan dan pengembangan untuk Menjadi wirausaha kuliner yang sukses dimana fokus Pada Mitra Usaha-uasaha rumah makan. Target umumnya adalah masyarakat desa Pineleng I Kabupaten Minahasa Induk serta target khususnya adalah mitra rumah makan pratiwi dan mitra rumah makan muslim yang berada Di Desa Pineleng I.

\section{Profil Kelompok Mitra}

Pelaksanaan Program Kemitraan Masyarakat yang dilaksanakan oleh Tim Pengabdian FEB Unsrat Pada Mitra Usaha rumah makan di Desa Pineleng Kabupaten Minahasa Provinsi Sulawesi Utara melibatkan Kelompok Usaha Kecil Menengah (UKM) Mitra I (Rumah Makan Pratiwi) Dan Mitra II (Rumah Makan Muslim). Kelompok usaha mitra adalah kelompok usaha kecil menengah yang mewadahi kelompok usaha-kelompok usaha kecil yang ada di Desa Pineleng I Kabupaten Minahasa Provinsi Sulawesi Utara. Kelompok Mitra I dan Mitra II ini merupakan kelompok usaha kecil yang secara umum membantu usaha-usaha kecil yang ada di daerah tersebut untuk memberikan solusi pengembangan bisnis yang ada. Mitra I (Rumah Makan Pratiwi) adalah sebuah usaha yang bergerak di bidang makanan (kuliner). Usaha Kecil ini didirikan dengan modal yang berasal dari pemiliknya sendiri dengan memanfaatkan lahan tempat tinggalnya yang merupakan hak milik dari pengusaha tersebut sebagai asset usahanya. Kemudian, Mitra II (Rumah Makan Muslim) adalah sebuah usaha yang bergerak di bidang makanan juga (kuliner). Usaha Kecil ini didirikan dengan modal yang berasal dari pemiliknya sendiri dengan memanfaatkan lahan tempat tinggalnya yang merupakan hak milik dari pengusaha tersebut sebagai asset usahanya. Dengan demikian, para pelaku usaha ini sangat membutuhkan strategi-strategi dalam mengembangkan usaha mereka kedepan dikarenakan terdapat banyak pesaing (competitor) di sekitar tempat mereka membuka usaha. Hal ini tentunya harus dibarengi dengan kemampuan yang mereka miliki saat ini dalam mengembangkan dan mempertahankan usaha mereka.

\section{Pelaksanaan Kegiatan (Implementasi)}

Kegiatan Program Kemitraan Masyarakat (PKM) ini dilaksanakan di Desa Pineleng I Kecamatan Pineleng Kabupaten Minahasa Provinsi Sulawesi Utara. Sebelum pelaksanaan kegiatan, Tim telah melakukan survei awal untuk mengetahui permasalahan masyarakat setempat dan kebutuhannya.

\section{Sistematik Keberlanjutan Usaha dan Perilaku Mitra}

Para pelaku usaha dalam hal ini mitra I (Rumah Makan Pratiwi) Dan Mitra II (Rumah Makan Muslim) di Desa Pineleng I Kabupaten Minahasa Provinsi Sulawesi Utara sangat menyadari perlu adanya pemahaman yang benar dan tepat mengenai Pelatihan dan Pengembangan Menjadi wirausaha yang sukses dalam menghadapi persaingan usaha saat ini, apalagi dalam era Asian Economic Comunity (AEC) ini. Para pemilik usaha menyadari pentingnya menjadi mitra yang ada di daerahnya guna memberikan masukan-masukan sebagai solusi atas setiap permasalahan yang terjadi untuk usaha kecil menengah (UKM). Kesadaran ini semakin dirasakan manfaatnya melalui kegiatan Program Kemitraan Masyarakat (PKM) yang dilaksanakan oleh Universitas Sam Ratulangi Manado yang bekerjasama dengan kelompok Mitra I (Rumah Makan Pratiwi) dan Mitra II (Rumah Makan Muslim) yang ada di Desa Pineleng I Kabupaten Minahasa Provinsi Sulawesi Utara. Dalam kegiatan penyuluhan, pelatihan dan pengembangan, pada sesi tanya jawab terlihat jelas bagaimana respon positif masyarakat dan kedua mitra (Rumah Makan Pratiwi dan Rumah Makan Muslim) terhadap materi yang dibawakan, dimana diidentifikasi masalah-masalah yang muncul yaitu:

1. Bagaimana agar supaya mereka terlatih dalam mengembangkan usaha mereka dengan menggunakan fasilitas teknologi informasi

2. Rendahnya soft skill, hard skill serta penguasaan teknologi informasi yang dimiliki kedua mitra dalam merebut pangsa pasar, sehingga menjadikan mereka tidak kreatif dan inovatif. 
3. Kurangnya pelatihan manajemen usaha kreatif secara intensif, pelatihan penggunaan akses teknologi informasi baik komputer maupun internet (berbasis online)

4. Kurangnya pendampingan yang dilakukan oleh pemerintah

\section{Analisis Kebutuhan}

Dalam perkembangan usaha ini para pemilik usaha (Mitra I) Dan (Mitra II) menyadari akan pentingnya pelatihan dan pengembangan Menjadi wirausaha sukses dalam persaingan usaha saat ini, dimana dalam hal ini salah satu komitmen untuk mendukung kegiatan dan program pemerintah dengan tujuan pertumbuhan ekonomi nasional sehingga seluruh masyarakat bisa sejahtera. Sebelum kegiatan pelatihan dan pengembangan dilakukan, Tim telah turun lapangan (survey) untuk pengambilan data awal, dimana hal ini dilakukan untuk mengetahui apa yang menjadi masalah dan kebutuhan masyarakat yang akan menjadi mitra kerja (Rumah Makan Pratiwi dan Rumah Makan Muslim) dalam kegiatan Program Kemitraan Masyarakat (PKM). Setelah pelatihan serta pengembangan maka akan dilakukan evaluasi dan feedback. Dimana terdapat beberapa masalah pokok, yakni: mereka kurang terlatih dalam menggunakan teknologi informasi (online business), mereka kurang memahami bagaimana cara mereka mengembangkan usaha, mereka menyadari bahwa rendahnya soft skill serta hard skill yang dimiliki dalam berwirausaha, sehingga menjadikan mereka tidak kreatif dan inovatif, kurangnya pelatihan manajemen usaha secara intensif, pelatihan penggunaan akses teknologi informasi baik komputer maupun internet dan kurangnya pendampingan yang dilakukan oleh pemerintah.

\section{Ketepatan Solusi Dalam Penanganan Permasalahan Mitra}

Para pemilik usaha mampu memahami secara baik dan benar dalam menerapkan pengetahuan yang ada mengenai konsep wirausaha (Pelatihan dan Pengembangan) untuk usaha kecil menengah yang ada, kemudian mereka dapat mengetahui dan memahami bagaimana menjadi seorang wirausaha sejati, strategi-strategi yang digunakan dalam konsistensi pelatihan dan pengembangan usaha, selanjutnya pemilik Usaha memiliki penguatanpenguatan SDM dalam kegiatan usaha mereka. Mereka bisa menciptakan pelayanan yang maksimal dan tepat waktu serta memperkuat jejaring sosial melalui sosial media melalui business online (market space), mereka sudah bisa menggunakan situs online jual-beli olx sehingga lebih luas dalam memasarkan produk-produk kuliner mereka.

Para pelaku usaha bisa menggunakan metode pelayanan tepat waktu yang akan berdampak pada peningkatan kinerja dan produktivitas usaha, kemudian mereka akan mempunyai kemampuan untuk berfikir logis, berdiskusi/berkomunikasi, mengevaluasi dan mengimplementasi setiap solusi yang ditawarkan.

\section{Keterbatasan Solusi Dalam Penanganan Permasalahan Mitra}

Kurangnya sumber daya pendukung dalam hal peralatan perangkat Teknologi Informasi (IT) dalam mengakses informasi secara global untuk dijadikan alat (Tools) bagi kegiatan usaha mereka, keterbatasan dana dalam mengembangkan usaha (ekspansi pasar), selanjutnya Keterbatasan waktu Tim pengabdian, sehingga hal ini berdampak pada kegiatan pengabdian dimana perlu dilakukan secara berkelanjutan sehingga usaha kecil menengah dapat terus diperbaharui pengetahuannya yang berhubungan dengan kewirausahaan guna mendukung kegiatan pengembangan usaha kecil menegah (UKM).

\section{Kesimpulan}

\section{PENUTUP}

Kegiatan ini mampu memberikan pelatihan dan pengembangan untuk Menjadi wirausaha kuliner yang sukses pada Mitra I (Rumah Makan Pratiwi) dan Mitra II (Rumah Makan Muslim) di Desa Pineleng I Kabupaten Minahasa Provinsi Sulawesi Utara, meningkatkan soft skill serta hard skill bagi pemilik usaha Rumah Makan Pratiwi dan pemilik Rumah Makan Muslim dalam berwirausaha, sehingga menjadikan mereka lebih kreatif dan inovatif, terciptanya pelatihan manajemen usaha secara intensif, pelatihan penggunaan akses teknologi informasi baik komputer maupun internet yang berbasis bisnis online, adanya pendampingan yang dilakukan oleh pemerintah secara profesional dan berkelanjutan 


\section{Saran}

Pengadaan program pelatihan, pengembangan dan evaluasi serta monitoring dari pihak pelaksana/Tim Program Kemitraan masyarakat harus dilakukan secara terus menerus (kontinuen), adanya pelatihan lebih lanjut (advance training) khususnya dalam peningkatan penguatan pada pengetahuan, ketrampilan dalam berwirausaha Pada kedua mitra Rumah makan (Kuliner), peran serta dari Three Helix (Akademisi, Pebisnis/Wirausaha, Pemerintah) sangatlah dibutuhkan dalam hal bekerja sama baik dalam hal sumbangsih pemikiran secara keilmuwan, implementasi praktis serta dari sisi kebijakan/regulasi, shifting Mindset dari para pelaku usaha untuk menciptakan peluang berwirausaha dengan tujuan menggerakkan berbagai macam sektor usaha kecil menengah (UKM) untuk meningkatkan pertumbuhan ekonomi nasional (national economic growth), karena hal tersebut mendukung program Nawacita Presiden Republik Indonesia saat ini

\section{DAFTAR PUSTAKA}

Dessler, Gary, 2011. Manajemen Sumber Daya Manusia. Penerbit Indeks, Jakarta.

Denny Triasmoko, Moch. Djudi Mukzam, Gunawan Eko Nurtjahjono. 2014. Pengaruh Pelatihan Kerja Terhadap Kinerja Karyawan (Penelitian pada Karyawan PT Pos Indonesia (Persero) Cabang Kota Kediri. Jurnal Administrasi Bisnis. Vol. 12 No. 1

Handoko, H. 2012. Manajemen Personalia dan Sumber Daya Manusia. Yogyakarta: BPFE

Hasibuan, S.P malayu (2007). Manajemen sumber daya manusia. Edisi Revisi. Jakarta : bumi aksara

Hikmat. 2006. Pemberdayaan Masyarakat dalam Pembangunan. Jurnal Perekonomian dan Kawasan Ekonomi Asia, Januari 2006

Indarti, N., dan Rostiani, R. 2008. Intensi Kewirausahaan Mahasiswa: Studi Perbandingan Antara Indonesia, Jepang dan Norwegia. Jurnal Ekonomika dan Bisnis Indonesia. 23(4), Oktober 2008

Mangkunegara. 2001. Manajemen Sumber Daya Manusia. Perusahaan cetakan pertama, penerbit PT. Remaja Rsodakarya. Bandung.

Nugroho, R. 2013. Memahami Latar Belakang Pemikiran Entrpeneurship Ciputra. Jakarta. Elex Media Komputindo

Trang, I. 2016. Competitive strength and its impact toward achieving company's performance based on balanced scorecard aproach in the furniture industry in central minahasa regency, Journal of Life Economics, Turkey. $3(2): 87-100$

Trang, I. 2017. Ibm Tentang Pelatihan Dan Pengembangan Menjadi Entrepreneur Berbasis Teknologi Informasi Pada Mitra Usaha Laundry Di Desa Pineleng I. Jurnal Ilmiah Manajemen Bisnis dan Inovasi. Vol 4. No. 2. https://ejournal.unsrat.ac.id/index.php/jmbi/article/view/17980 